\title{
Vavilov's concept of the species as a system
}

\author{
Boguslav S. Kurlovich \\ International North Express Co. Liesharjunkatu 9, 53850 Lappeenranta, Finland.
}

How to cite this paper: Kurlovich, B. S. (2019) Vavilov's concept of the species as a system. International Journal of Food Science and Agriculture, 3(4), 275-286.

DOI: $10.26855 /$ ijfsa.2019.12.003

*Corresponding author: Boguslav $\mathrm{S}$. Kurlovich, International North Express Co. Liesharjunkatu 9, 53850 Lappeenranta, Finland.

Email: bkurl1@hotmail.com

\begin{abstract}
The majority of scientific investigations in the area of a plant taxonomy are finished usually on the level of a concrete species. N. Vavilov in a study of several hundred species showed the absence of monotypic species, i.e. species represented by various forms. The investigation of cultivated species has led to the Vavilov's conception of a Linnaean species as a definite system. We also have tried to complement and develop the Vavilov's concept concerning species of Lupinus L. The International Code of botanical nomenclature fixed such categories as subspecies (subspecies), varieties (varietas), subvarieties (subvarietas) and form (forma). Besides, N. Vavilov paid special attention to eco-geographical differentiation of species into ecotypes, geotypes, concultivars, etc. Such an approach is very effective at the systematization of agricultural plant biodiversity.
\end{abstract}

We have taken advantage of the concept of Vavilov in relation to our model object - genus Lupinus L. Many years of research (1973-2014) by means of expedition missions in many countries, by the study the lupins collection of the N. I. Vavilov's Institute (2500 accessions) in various geographic regions, and by generalization of the data obtained by other researchers, have enabled as to find out new regularities in the variability of characters depending on genetic features of the species and accessions, and also on ecological and agronomic conditions of their growth (Kurlovich et al. 1990). This Vavilov's approach allowed us to develop a more detailed intraspecific taxonomic and eco-geographical classification and proposed efficient ways of lupins genetic resource utilization in breeding (Kurlovich, 1989, 1998, 2002; Kurlovich and Stankevich, 1990, 1994; Kurlovich et al. 1995).

\section{Keywords}

Lupins, Vavilov, Komarov, species, taxonomy, classification, intraspecific diversity, plant breeding

\section{Introduction}

WHAT IS A SPECIES? There are numerous concepts of species at the research level. Mayden's (1997) list of 22 distinct species concepts along with synonyms is a useful starting point for a review. John Wilkins (2006) made several additions and clarifications. The following definitions can be used to summarize their materials:

(1) The taxonomic rank, and the most basic unit or category of biological classification.

(2) An individual belonging to a group of organisms (or the entire group itself) having common characteristics and (usually) are capable of mating with one another to produce fertile offspring.

(3) A group of living organisms consisting of similar individuals capable of exchanging genes or interbreeding. The species is the principal natural taxonomic unit, ranking below a genus and denoted by a Latin binomial, e.g., Homo sapiens. 


\section{Methodology}

Our further reasoning will be applied to leguminous plants. Plant identification connects to the science of taxonomy or classification. "Father of modern taxonomy" Carolus Linnaeus (1735) developed the current taxonomical system in the 18th century, classifying plants based on their relationships to each other and organizing them in a hierarchy beginning with kingdom (a collection of organisms that share basic traits) and descending to species, organisms so closely related that they can produce fertile offspring together. Plants belong to the plant kingdom. Determining which taxonomical groups, or taxa, they belong to after that helps you proceed to identify a precise species. A species is given a two-part name: the generic name and the specific name (or specific epithet). For example, Lupinusalbus L.

Two famous Russian botanists made a significant contribution to the study of plant species: Nikolaj I. Vavilov and Vladimir L. Komarov. Ideas of V.L. Komarov were based on monotypic species, according to which species cannot include a systematic unit of a lower rank. According to his idea, a species is a morphological system plus geographic distinctness. (Komarov, 1931; Krassilov, 1989).

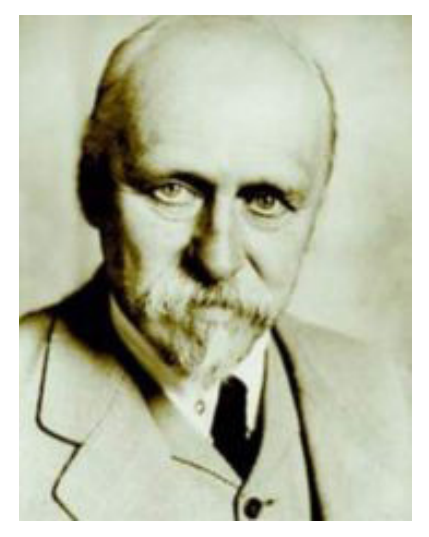

Figure 1. Vladimir L. Komarov

N.I.Vavilov, however, in a study of several hundred species showed the absence of monotypic species, i.e. species represented by various forms. N.I. Vavilov formulated a polytypic species concept at the $5^{\text {th }}$ INTERNATIONAL BOTANICAL CONGRESS in Cambridge in August 1930; put forward the ideas of multiformity of species, the relativity of taxonomic criteria and the theory of peripheral accumulation of recessive characters. From the evolutionary point of view, he considered species as knots in evolutionary chains. Vavilov sought an aphoristic definition of the kind given by the then also well-known botanist V.L. Komarov: a species is a morphological system plus geographic distinctness. Elaborating on this, Vavilov defined a "Linnaean species" as "an isolated complex dynamic morphphysiological system bound in its origin to a certain environment and area" (Vavilov, 1931a, p.215).

N.I. Vavilov's whole attention has been devoted to the intraspecific diversity of separate plants, to the botanical study of the varietal diversity of separate Linnaean species including cultivated plants, and the study of the geography of varieties in ancient and modern agricultural countries. The investigation of several hundred cultivated species, carried on by a group of scientific workers, according to a strictly defined plan, has led to the conception of a Linnaean species as a definite system.

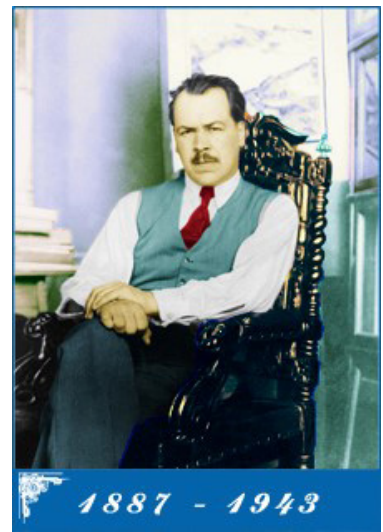

Figure 2. NikolajI.Vavilov 
The chief regularity determining the diversity of a Linnaean species, its system, has been called by Vavilov «the Law of homologous series in variation» (Vavilov, 1920). The term "homologous" applies according to Vavilov chiefly to the species within the limits of the same genus. In comparing different genera it would be sometimes more to the point to speak of parallelism in analogous variation. In studying the one or the other species, we, as a rule, draw up a system of hereditary variation for all characters, including the characters of the reproductive organs, as well as the vegetative characters and the biological peculiarities. The vast mass of facts has led Vavilov to the conception of a Linnaean species as a system of forms, the building up of which is controlled by the law of homologous series. The conception of a Linnaean species, as a regular system, seemed to Vavilov of great importance for practical purposes connected with the investigation of cultivated plants, as well as for the botanical study of the principal question of the process of evolution. A close study of the evolution process, in the light of Vavilov's conception of a species, is possible only in considering the Linnaean species as a system. Only the knowledge of the geography of the chief potential or varietal characters (genes) will lead to a real mastery of the species (N.I. Vavilov, 1931a, p.214). He has suggested that the method of differential systematic and differential geography should be used for the study of species. Concerning plants which are of importance in cultivation, this is the only way of mastering the Linnaean species. The study of a species embraces not only morphological but also physiological characters. Many Linnaean species represent a complex system of ecotypes or climatypes. It is natural that differentiating in space, and under going the influence of selection, the principal potential of a Linnaean species singles out groups of hereditary forms most adapted to the given environment. Thus, a Linnaean species is according to Vavilov's conception (1931a, p.215), a separate morph physiological system connected in its genesis with a definite environment and area. In opposition to the rather common notion as to the relativeness of species and the conventional character of their understanding, the great number of concrete facts encountered in studying the cultivated plants and their wild relatives has induced Vavilov to recognize the Linnaean species as actual complexes, actual systems, which exist in Nature and represent important definite links in the evolutional chain, the know ledge of which is very helpful in mastering the multifariousness of the organized world. The concrete material shows that the so-called "Linnaean species, may be very different regarding their contents. Being more or less separate systems, they manifest themselves in a different compass. The analysis of a great number of Linnaean species using the method of differential systematic and differential geography, as well as by the modern methods of genetics and cytology, reveals the great diversity of the species. Thus, there are sometimes bulky systems belonging to one Linnaean species, which might be expediently subdivided into categories or subspecies. Sometimes, on the contrary, a Linnaean species represent a very limited and comparatively small system. The law of homologous series in hereditary variation answers the question of what material should be looked for, while the theory of the centers of origin of cultivated plants provides an answer to the question where it could be found. To study intraspecific diversity and to determine the centers of origin of cultivated plants, Vavilov and his followers used a differential systematic and geographical method of crop studies (Vavilov, 1931a,b) which meant as follows: - differentiation of a genus into species and intraspecific diversity with the help of morphological, hybridylogical, cytological and others methods; determination of the genotypic composition of a species; geographical localization of hereditary forms of a species as well as the centers of their diversity. Such an approach supported by the development of different intraspecific classifications helped to accomplish a profound and comprehensive analysis of intraspecific and varietal diversity of cultivated plants and find ways of efficient utilization. In this respect, the International Code of botanical nomenclature fixed such categories as subspecies (subspecies), varieties (varietas), subvarieties(subvarietas) and form (forma).

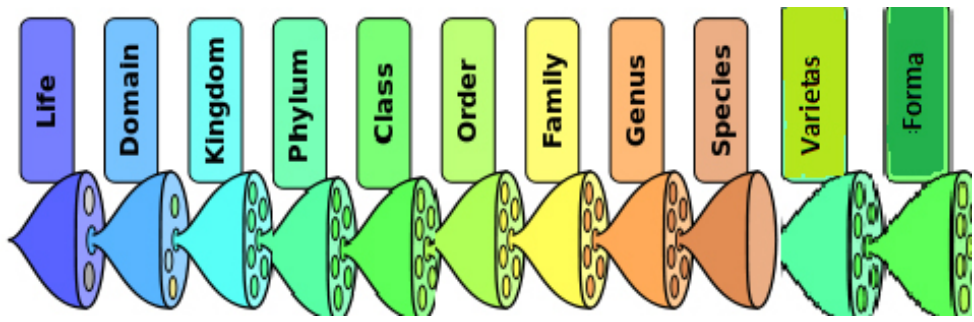

Figure 3. The hierarchy of biological classification's taxonomic ranks. (Intermediate minor rankings are not shown)

Besides, Vavilov gave special heed to eco-geographical differentiation of the species into ecotypes, geotypes, concultivars, etc. (Vavilov, 1931b, 1965a; Sinskaja, 1969). The postulate of the species as a complex multilateral phenomenon would urge a researcher to use diverse methods for identifying differences between intraspecific categories. In addition to the main morphological method, the scientists of the Vavilov Institute have widely used anatomic, cytological, carpological, paleo botanical, ontogenetic, biochemical, physiological, geographical, and genetic and other 
methods. Such a comprehensive approach is especially efficient when the intraspecific diversity of cultivated lupin forms is concerned. This Vavilov's differential systematic and geographical method of crop studies is interconnected with other findings of N.I. Vavilov and is based on his law of homologous series in hereditary variation, his theory of the centers of origin (diversity) of cultivated plants, and his concept of the species as a system (Вавилов, 1920, 1926, 1935, 1987b).

Vavilov paid special attention to leguminous plants. Most of his theoretical generalizations are based on the research of vetch, lentils, been, lupins and other legumes. Valuable accessions of white lupin (Lupinus albus L.) were collected by Vavilov during his trip to the Mediterranean in 1926. He managed to find very early, thermally neutral and small-seeded forms in Palestine, relating to the Jordanian ecotype. In particular, the duration of the growing period of the sample Tel Karam (k-290) in the conditions of Ukraine was only 105 days. From Sudan, Vavilov brought, on the contrary, very late, but highly productive and large-seeded forms belonging to the Sudanese ecotype (k-486, k-495). Of special value as sources for lupin breeding in Russia, Poland and Ukraine were samples of the Jordanian ecotype from Palestine. Their hybridization with samples of the Georgian ecotype (Kurlovich, 1996), and also their involvement in combinations with the application of mutagenesis, allowed V.I. Golovchenko to create early and high productive cultivars of white lupin, Kievsky mutant, Horizont and Druzba, suitable for the condition of Russia and Ukraine (Golovchenko et al, 1984).

All Vavilov's fundamental ideas interconnected among themselves and represent a complex doctrine about the global genetic diversity of plants and their systematization and classification. Based on this doctrine, the experts of the Vavilov Institute (VIR) have developed intraspecific classifications practically for all leguminous crops. Vavilov invited his friend L.I. Govorov to manage the Leguminous crop department, and he recruited experts in leguminous plants to the staff. Govorov developed an intraspecific classification for peas (Govorov 1937), organized breeding work with leguminous crops in the former USSR and created many pea cultivars. Govorov had a tragic destiny; he was arrested and disappeared like Vavilov. P.M. Zhukovsky was invited to manage the lupin collection. He developed and published important works on interspecific and intraspecific diversity of lupins (Zhukovsky 1929). Research on the genetic resources of lentil was done by Vavilov's wife E.I. Barulina (Barulina 1930). During the Second World War, the department of leguminous crops was managed by N.R. Ivanov, who made a substantial contribution to preserving the collection during the siege of Leningrad. He carried out important research on the genetic resources of kidney bean (Ivanov 1961). After the Second World War, the systematization of the leguminous plant was done under the direction of Korsakov (Korsakov 1971). Intraspecific classifications for peas were developed (Govorov, 1937; Makasheva, 1973, 1979), mung bean (Popova, 1937), soybean (Korsakov, 1971, Teplyakova, 1997), chickpea (Seferova, 1997), and vetch (Stankevich and Rep'ev, 1999). Scientists of the Komarov's Botanical Institute (Yakovlev et al. 1996; Gomcharov, 2013) also published valuable materials on different leguminous plant classifications. These classifications make it possible to disclose completely the potential of leguminous crops, and they are widely used in breeding practice and plant science. Numerous scientists in many countries continue the traditions and methods of Vavilov. Ideas of Vavilov on the field of leguminous crops have been further developed in Australia (Gladstones, 1974, 1998; Sweetingham, 1986, 1989; Cowling, 1994; Clements and Cowling, 1990, 1991), Finland (Tigerstedt, 1994), South Africa (Van Wyk, 2003); Germany (Diederichsen and Hammer, 1996), Poland (Swęcicki W, 1988; Swęcicki W.K., 1996; Kazimierski and Kazimierska, 1992; 1994), Portugal (Mota, 1984; Gusmão, 1988 ; Gusmão et al., 1996; Tavares de Sousa et al., 1992; Neves Martins; 1994; Dordio, 1996), Sweden (Blixt, 1970, 1996), UK (Polhill, 1976, Bisby, 1981; Ambrose, 1996; Levis et al., 2005; Hughes and Eastwood, 2006); Canada (Anne Bruneau et al. 2013 ); USA(Herendeen et al. 2013, Wojciechowski, 2002) and many others.

\section{Objectives}

We have worked in the Vavilov Institute (VIR) 32 year and have taken advantage of the concept of Vavilov in relation to our model object - genus Lupinus L., numbering several hundred species (Hughes and Eastwood, 2006), focused our research on three species of lupins (Lupinus albus L., L. angustifolius L. and L. luteus L.). The system of these species was reviewed using Vavilov's concept of the species as a system, and applied his differential systematic and geographical method in our studies. This approach provided a possibility to perform a targeted search of genetic resources of lupins, to solve problems of their evolution and selection. It enabled us not only to cast light on the diversity of lupin forms but also to reveal a series of regularities in their variation depending on the degree of cultivation, geographic environments and soil conditions. Such an outcome, in its turn, helped in finding and recommending valuable initial material for breeding.

\section{Results and discussion}

Each form of lupin can be assessed as an object fitting in with a number of consecutive taxa. We recognize subspecies 
as an isolated group of individual plants within a population of a species concerning lupins. They occupy certain part of the area of a species, constitute together a mobile system, are able to cross among themselves and with plants growing in other parts of the area of this species, produce prolific progeny, possess distinctive morphological and inheritable characters in vegetative and generative organs with the uniform genetic base, and incorporate transient forms (Kurlovich, 2002). Allelism and character complementarities tests have shown that in lupins the color of seed is correlated with the color of the corolla. This linkage reflects the stability of the genetic system, which corresponds to the rank of varieties. A good diagnostic character is the color of vegetative parts, and the absence or presence of anthocyanin, in particular. Being less stable, it could be used in identifying subvarieties. Considerable practical interest for breeders may be generated by the plants with determinate branching, fascicular stem and other characters of breeding value. Such forms are theoretically possible in all the varieties and subvarieties. Therefore, it seems justified to regard them in the rank of form (f.).

\section{White lupin (Lupinus albus L.)}

The scheme of classification of Lupinusalbus L.

1. Subsp. graecus (Boiss. et Spun.) Franko et Silva

2. Subsp. termis (Forsk.) Ponert.

1. Var. abissinicus Libk.

2. Var. subroseus Libk.

3. Subsp. albus L.

3. Var. albus

4. Var. vavilovii (Atab.) Kurl. et Stankev.

5. Var. vulgaris Libk.

\section{f. libkindae Kurl. et Stankev.}

The full description of the above-mentioned taxa by the International Code of Botanical Nomenclature is described in the following works (Kurlovich and Stankevich 1990, Kurlovich, 2002). Lupinus albus is widely spread as wild and cultivated plants over all the Mediterranean regions and many Countries of the World (fig.4).

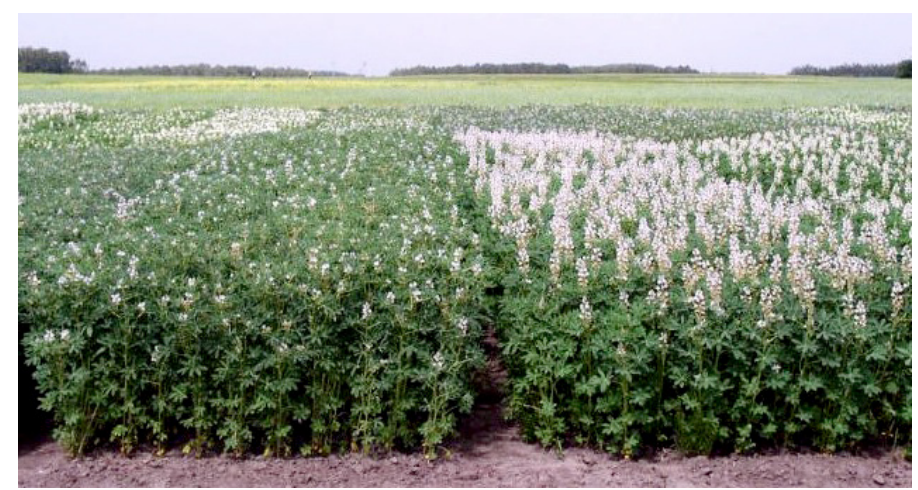

Figure 4. White lupin (Lupinus albus L.)

The ancient culture of white lupin under the local name «hanchcoly» until recently existed in Western Georgia (Kurlovich, 1996a). The closest described neighbors of this species were: L. graecus and L.termis. The first is the wild plant on the Balkan Peninsula; the second is grown in Egypt, Libya, Sudan, Ethiopia, Israel, Palestine, and Syria. Information accumulated by scientists made it possible to revise and integrate the volumes of these species.

All three species differ only in the color and size of flowers and seeds (quantitative characters). Cultivated forms of white lupin were introduced in agricultural practice a long time ago, before ancient times, in the place of presenttime Greece. To the south (Egypt, Libya, Palestine) mainly the forms with white seeds and pink-and-blue or lightpink flowers (L. termis) were spread, while westwards (Apennine Peninsula and farther) mostly the forms with white seeds and grayish-blue or white seeds (L.albus) dispersed. White lupin (L.albus) is still grown in Greece, where wild L.graecus is also spread. But, the absence of distinct specific characters makes it possible to consider all three 
species harbored within the limits of one species of Linnaeus (Lupinus albus). But the existence of geographical and physiological differentiation is sufficient to recognize them as having the rank of subspecies in L.albus L: subspecies. albus, subspecies graecus (Boiss. et Sprun.) Franco et Silva, and subspecies termis (Forsk.) Ponert (Kurlovich, 1990, 1998; Kurlovich et al. 1995).

\section{Narrow-leafed lupin (Lupinus angustifolius L.)}

Using the developed criteria of intraspecific taxa, VIR's narrow-leafed lupin collection (L. angustifolius L.) was screened to identify 13 varieties distinctly differing from each other in the color of seeds and the corolla. Variations in the color of cotyledons, vegetative parts, and carina have been used for the identification of 12 subvarieties. Besides, the plants with determined branching and fascicular stems are described as 8 separate forms (Kurlovich and Stankovich 1990). Intraspecificic classification of narrow-leafed lupin (Lupinus albus L.) developed by us looks as follows:

Intraspecific Classification of Lupinus angustifolius L.

1. Var. angustifolius, 1990. Bull. Appl. Bot. Gen. Pl.-Breed., 135:23 - Flowers blue. Seed motley, gray with unclear spotting.

1. Subvar. angustifolius - Cotyledons and the carina's edge anthocyan - coloured.

1. f. angustifolius - Side shoots absent or shortened, flowers axillary.

2. Subvar. viridulus Kurl. et Stankev. 1990, 1.c.:24. - Cotyledons and the carina`s edge green.

2. Var. albopunctatus Kurl. etStankev. 1990, 1.c.:24. - Flowers blue. Seed almost black with tiny white dots and spots.

3. Var. griseomaculatus Kurl. etStankev. 1990, 1.c.:24. - Flowers blue. Seed gray with white spots.

4. Var. chalybeus Kurl. et Stankev. 1990, 1.c.:24. - Flowers blue. Seed white with sparse dark-brown and gray spots.

5. Var. corylinus Kurl. et Stankev. 1990, 1.c.:24. - Flowers blue. Seed beige with browm spots.

3. f. zhukovskii Kurl. et Stankev. 1990, 1.c.:24. - Side shoots absent or shortened, flowers axillary.

6. Var. purpureus Kurl. et Stankev. 1990, 1.c.:24. - Flowers pink. Seed motley or gray with unclear spotting.

3. Subvar. purpureus - Cotyledons anthocyan - coloured, vegetative parts dark-violet.

4. f. deramosus Taran. et Busch. exKurl. 1990, 1. c.:24. - Side shoots absent or shortened, flowers axillary.

4. Subvar. rhodanthus Kurl. etStankev. 1990, 1. c.:25. - Cotyledons and vegetative parts green.

7. Var. rubidus Kurl. et Stankev. 1990, 1. c.:25. - Flowers pink. Seed almost black with tiny white dots and spots.

5. Subvar. rubidus - Cotyledons anthocyan-coloured, vegetative parts dark-green.

6. Subvar. maissurianii Kurl. et Stankev. 1990, 1. c.:25. - Cotyledons and vegetative parts anthocyan-coloured.

5. f. epigonalus Taran. et Busch. exKurl. - Side shoots absent or shortened, flowers axillary.

8. Var. atabekovae Kurl. et Stankev. 1990, 1. c.:25. - Flowers pink. Seed with white spots.

9. Var. sparsiusculus Kurl. et Stankev. 1990, 1. c.:25. - Flowers pink. Seed white with sparse dark-brown and gray spots.

10. Var. brunneus Kurl. et Stankev. 1990, 1. c.:25. - Flowers pink. Seed beige with brown spots.

11. Var. albosyringeus Taran. ex Kurl. et Stankev. 1990, 1. c.:26. - Flowers pale-violet. Seed white, dull at the scar, without a triangular spot or strip.

7. Subvar. albosyringeus - Cotyledons without anthocyan, vegetative parts dark-green.

6. f. kloczkovii Kurl. et Stankev. 1990, 1. c.:26. - Side shoots absent or shortened, flowers axillary.

7. f. confertus Kloczko et Kurl. 1990, Bull. VIR, 206:82. - Stem fascicular. Flowers, pods and side shoots clustered at the top of the stem.

8. Subvar. polonicus Kurl. etStankev. 1990, Bull. Appl. Bot. Gen. Pl.-Breed., Leningrad, 135:26. - Cotyledons and vegetative parts anthocyan - coloured.

9. Subvar. lilacinus Kurl. et Stankev. 1990, 1. c.:26. - Cotyledons and vegetative parts light-green.

12. Var. albidus Kurl. et Stankev. 1990, 1. c.:26. - Flowers white. Seed white with sparse brown spots.

8. f. kuptzovii Kurl. et Stankev. 1990, 1. c.:26. - Side shoots absent or shortened, flowers axillary.

13. Var. candidus KuptzovetKurl. 1990, Bull. Appl. Bot. Gen. Pl.-Breed., Leningrad, 135:26. - Flowers white. Seed sheen-white, glossy.

10. Subvar. candidus - Cotyledons and and vegetative parts without anthocyan. 
11. Subvar. virescens Kuptzov et Kurl. 1990, 1. c.:26. - Cotyledons anthocyan -coloured. Vegetative parts without anthocyan.

12. Subvar. violaceus Kuptzov et Kurl. 1990, 1. c.:27. - Cotyledons and vegetative parts anthocyan - coloured.

Narrow-leafed lupin is characterized by a broad polymorphism in both morphological and physiological characters. Macro- and microseismic plants and the forms with broad and narrow leaflets occur over all the Mediterranean. Besides, no wide gap was observed between cultivated and wild forms (Fig.5).

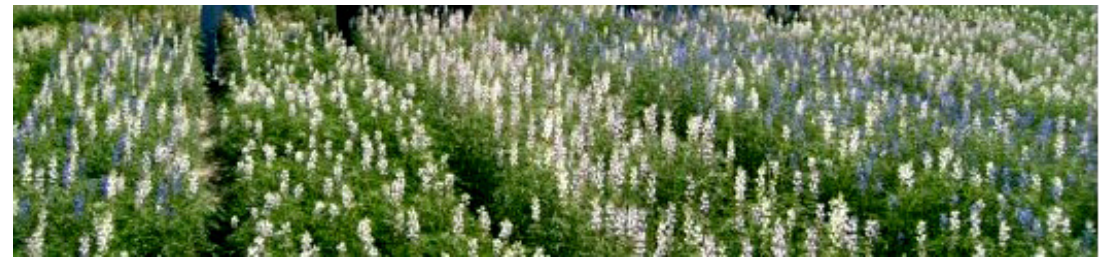

Figure 5. Narrow-leafed lupin ((Lupinus angustifolius L.)

In view of this, there is no reason to insist on the existence of two species: L. linifolius Roth. and L. opsianthus Atab. et Maiss., and two subspecies: subsp. angustifolius and subsp. reticulatus (Desv.) Franco et Silva, which have been set apart only because they have different width of leaflets and size of seeds (quantitative characters). We suppose that it would be more correct to subdivide this species into varieties, subvarieties, and forms based on morphological variation, and into geotypes, ecotypes, eco-geographic groups of ecotypes and concultivars based on physiological, biochemical, economic and other parameters, similar to white lupin. This approach provided us with a possibility to identify a series of similar ecotypes within the limits of different geotypes, where variations had definite geographic regularities.

\section{Yellow lupin (Lupinus luteus L.)}

Variability of characters at yellow lupin (Lupinus luteus L.) is less expressed than in L. angustifolius; however, a homologous series can be modeled on the color of seeds, which is more or less similar to L. angustifolius. Dominating coloring of flowers is yellow or, less frequently, lemon-yellow, orange or whitish (Fig.6).

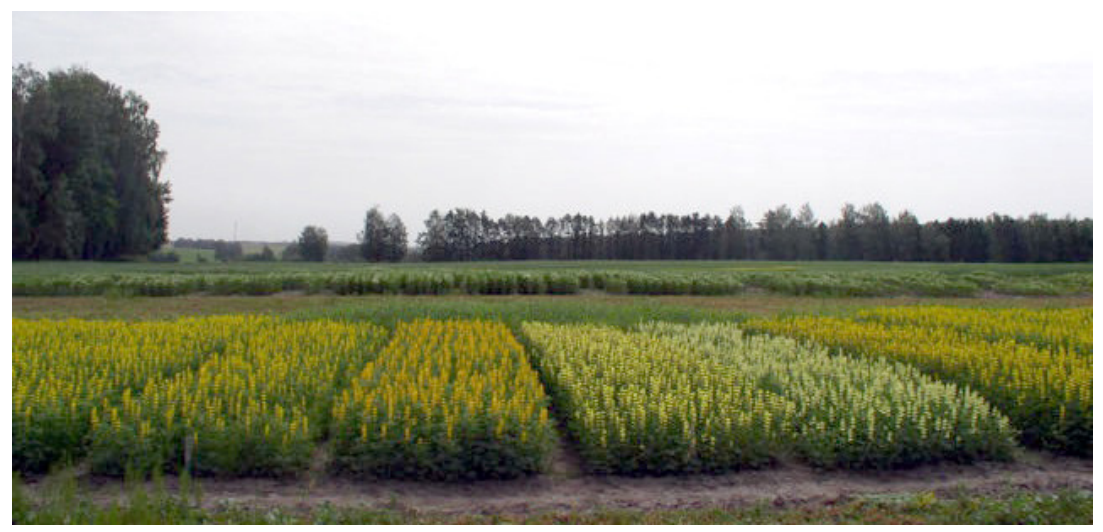

Figure 6. Yellow lupin (Lupinus luteus L.)

Using combinations of such characters as the color of the corolla, the carina's edge, vegetative organs and seeds, 18 varieties, 4 subvarieties, and 6 forms have been identified (Kurlovich and Stankevich,1990, Kurlovich, 2002, 2015).

Intraspecific Classification of Lupinus luteus $\mathrm{L}$.

1. Var. luteus, 1990. Bull. Appl. Bot. Gen. Pl.-Breed135:28. - Flowers yellow. Seed white with black dots without arcs.

1. f. volovnenkoae Kurl. etStankev. 1990, 1. c.:28. - Side shoots absent or shortened, flowers axillary.

2. f. compactus Kazim. et Kaz. Ex Kurl. 1990, 1. c.:28. - Flowers and pods clustered at the top of the stem.

2. Var. maculosus Kurl. et Stankev. 1990, 1. c.:28.- Flowers yellow. Seed white with black spots and two light arcs.

3. Var. kazimierskii Kurl. etStankev. 1990, 1. c.:28.- Flowers yellow. Seed white with brown spots without arcs.

4. Var. arcellus Kurl. et Stankev. 1990, 1. c.:28. - Flowers yellow. Seed white with brown spots and two dark arcs.

5. Var. sempolovskii Kurl. et Stankev. 1990, 1. c.:28.-Flovers yellow. Seed white with black spots and wide clear space 
round the scar.

6. Var. melanospermus Kurl. et Stankev. 1990, 1. c.:29.- Flower yellow. Seed brown-and-black with light arcs.

7. Var. niger Kurl. etStankev. 1990, 1. c.:29.- Flowers yellow. Seed black, without arcs.

8. Var. cremeus Kurl. et Stankev. 1990, 1. c.:29.- Flowers yellow. Seed cream with white arcs.

9. Var. leucospermus Kurl. etStankev. 1990, 1. c.:29.- Flowers yellow. Seed white.

1. Subvar. leucospermus - Carina`s edge without anthocyan.

3. f. ucrainicus Kurl. etStankev. 1990, 1. c.:29.- Side shoots absent or shortened, flowers axillary.

2. Subvar. taranuchoi Kurl. etStankev. 1990, 1. c.:29.- Carina`s edge with anthocyan.

10. Var. citrinus Kurl. et Stankev. 1990, 1. c.:29.- Flowers lemon-yellow. Seed white with black dots without arcs (doted).

4. f. lukasheviczii Kurl. etStankev. 1990, 1. c.:29.- Side shoots absent or shortened, flowers axillary.

11. Var. sulphureus Kurl. et Stankev. 1990, 1. c.:30. - Flowers lemon-yellow. Seed white with black spots and two light arcs.

12. Var. stepanivae Kurl. et Stankev. 1990, 1. c.:30. - Flowers lemon-yellow. Seed creme-coloured with two white arcs.

13. Var. ochroleucus Kurl. et Stankev. 1990, 1. c.:30. - Flowers lemon-yellow. Seed white.

3. Subvar. ochroleucus - Carina`s edge with anthocyan.

4. Subvar. chloroticus Kurl. etStankev. 1990, 1. c.:30. - Carina's edge without anthocyan.

5. f. bernatzkayae Kurl. etStankev. 1990, 1. c.:30. - Side shoots absent or shortened, flowers axillary.

14. Var. auranticus Kurl. etStankev. - Flowers orange. Seed white with black dots without arcs.

15. Var. croceus Kurl. etStankev. - Flowers orange. Seed white with black dots and light arcs.

16. Var. aureus Kurl. etStankev. - Flowers orange. Seed white.

6. f. golovczenkoi Kurl. etStankev. - Side shoots absent or shortened, flowers axillary.

17. Var. albicans Kurl. etStankev. - Flowers whitish. Seed white with black spots and two light arcs.

18. Var. sinskayae Kurl. etStankev. - Flowers whitish. Seed white.

The intraspecific classifications of lupins developed by us on the basis of the Vavilov approach are widely used for identification of genetic resources and their use in lupins breeding.

\section{Conclusions}

My colleagues and I are supporters of the concept of Vavilov about a Linnaean species as a definite system. N.I.Vavilov showed the absence of monotypic species, i.e. species represented by various forms. Vavilov formulated a polytypic species concept at the $5^{\text {th }}$ INTERNATIONAL BOTANICAL CONGRESS in Cambridge in August 1930; put forward the ideas of multiformity of species, the relativity of taxonomic criteria and the theory of peripheral accumulation of recessive characters. From the evolutionary point of view, he considered species as knots in evolutionary chains. Vavilov sought an aphoristic definition of the kind given by the then also well-known botanist V.L. Komarov: a species is a morphological system plus geographic distinctness. Elaborating on this, Vavilov defined a "Linnaean species" as "an isolated complex dynamic morph-physiological system bound in its origin to a certain environment and area" (Vavilov, 1931, p.215). This led to the understanding of the Linnaean species concept, an integral entity consisting of closely interlinked components where the whole and the parts are merged (Vavilov 1965a; Agaev 1987; Korovona 1987). We also have tried to complement and develop the Vavilov's concept concerning lupins. Vavilov's concept of the species as a system has enabled as to find out new regularities in the variability of characters in lupins depending on genetic features of the species, and also on ecological and agronomic conditions of their growth. This approach allowed us to develop a more detailed intraspecific taxonomic and eco-geographical classification and proposed efficient ways of lupins genetic resources utilization in breeding.

Vavilov was the first to recognize the necessity for intensive plant collecting and preservation. He was a highly qualified collector of plant genetic resources and manager of collecting missions and an author of many theoretical and practical ideas in the field of the global genetic diversity of cultivated plants. A major contribution of Vavilov was his ability to translate his rapidly growing scientific knowledge in genetic resources into economic use. Vavilov's plant collecting expeditions served as the basis for the leguminous crop collection in VIR, which provided the initial materials for over $75 \%$ of new grain legume cultivars created in Russia and other countries of the former USSR (Kurlovich 1996b, 2002). 
It is very difficult to do justice to Vavilov in this short article. The scope of Vavilov's interests was extraordinarily wide and included practically all crops and disciplines of plant science. The memory of Vavilov has been preserved through his collections of plant genetic resources, ideas, books, and followers. These are an important legacy of N.I. Vavilov, and were recently documented posthumously in his book 'Five Continents' (Vavilov 1962, 1987a, 1997).

\section{Acknowledgments}

The work was done at the expense of the Russian state financing of the N.I. Vavilov All-Russian Institute of Plant Industry.

We wish to express our gratitude to scientists of this Institute: to Prof. M.G. Agaev and Drs A.K. Stankevich and O.N. Korovina for the help, valuable counsel and participation in the development of intraspecific classifications for leguminous crops.

\section{Conflicts of Interest}

The author declare no conflicts of interest

\section{References}

Agaev, M.G. 1987. Vavilov's conception of species and its development. GeneticaXXIII(11):1949-1960.

Ambrose, M. 1996. Grain legume collections and activities in the UK. Pp.100-102 in Report of a Working Group on Grain Legumes (T. Gass, M. Ambrose, J. Le Guen, A. Hadjichristodoulou and S. Blixt, compilers). ECP/GR-Grain Legumes Network, IPGRI, Rome, Italy.

Anne Bruneau, Jeff J. Doyle, Patrick Herendeen, Colin Hughes, Greg Kenicer, Gwilym Lewis, Barbara Mac-kinder, R. Toby Pennington, Michael J. Sanderson, and Martin F. Wojciechowski. 2013 Legume phylogeny and classification in the 21st century: Progress, prospects, and lessons for other species-rich clades. //TAXON 62 (2) April 2013: 217-248.

Barulina, E.I. 1930. Lentil in USSR and other countries. Bull. Appl. Bot. Genet. Plant Breed. (Leningrad), Supplement 40:1-319.

Bisby, F.A. 1981. Genisteae. Pp. 409-425 in Advances in Legume Systematics, Part 1 (R.H. Polhill and P.H. Raven eds.). Royal Botanic Gardens, Kew, UK.

Blixt, S. 1970. Studies of induced mutations in peas. XXVI. Genetically conditioned differences in radiation sensitivity. Agr. Hort. Genet., Bd. 28:55-116.

Blixt, S. 1996. Status of legume collections in the Nordic countries. Pp. 61-62 in Report of a Working Group on Grain Legumes (T. Gass, M. Ambrose, J. Le Guen, A. Hadjichristodoulou and S. Blixt, comps). ECP/GR-Grain Legumes Network, IPGRI, Rome, Italy.

Cowling, W.A. 1994. Use of lupin genetic resources in Australia. Pp. 9-18, in Advances in Lupin Research (J.M. Neves Martins and M.L. Beirao da Costa, eds.). Proceeding of the 7th International Lupin Conference, Evora, Portugal. ISA Press, Lisbon, Portugal.

Diederichsen, A. and K. Hammer. 1996. Status of plant genetic resources and research on grain legumes in Germany. Pp.45-50 in Report of a Working Group on Grain Legumes (T. Gass, M. Ambrose, J. Le Guen, A. Hadjichristodoulou and S. Blixt, comps). ECP/GR-Grain Legumes Network, IPGRI, Rome, Italy.

Gladstones, J.S. 1974. Lupin of the Mediterranean region and Africa. W. Aust. Dept. Agr. Tech. Bull. 26.48 p.

Gladstones, J.S. 1998. Distribution, origin, taxonomy, history and importance. Pp. 1-39 in Lupin as Crop Plants. Biology, Production and Utilization (J.S. Gladstones, C. A. Atkins and J. Hamblin, eds.). Cambridge University Press, Cambridge, UK.

Golovchenko, V.I., N.S. Kucherenko, N.G. Lesunova and A.S. Porokonnyij. 1984. Genefund and the result of breeding fodder lupine. Res. Bull., N.I. Vavilov Inst. Plant Ind., Leningrad, USSR 139:7-12.

Goncharov,M.Y. 20013. Taxonomic revision of the tribe Baphieae (Baphia clade). P.63 in „Towards a new classification szstem for Legumes". Abstr. of 6th Intern. Legume Conference, Johannesburg, South Africa. 
Govorov, L.I. 1937. Pea. Pp. 229-336 in Flora of Cultivated Plants. State Printing Office, Moscow and Leningrad, USSR.

Hill, J., H.C. Becker and P.M.A. Tigerstedt. 1998. Quantitative and Ecological Aspects of Plant Breeding. Chapman \& Hall, London, UK. 275 p.

Hughes Colin and Ruth Eastwood. 2006. Island radiation on a continental scale: Exceptional rates of plant diversification after uplift of the Andes, PNAS, http://www.pnas.org/content/103/27/10334

Ivanov, N.N., M.I., Smirnova, N.I. Sharapov et al. 1932. Problem of alkaloid-free lupin. Exhibit 54 to Bull. Appl. Bot. Genet. Plant Breed. 63 pp.

Ivanov, N.R. 1961. Kidney bean. State Printing Office, Moscow and Leningrad, USSR. 280 pp.

Kazimierski, T. and E.M. Kazimierska. 1992. Natutalne tetraploidy lubinu bialego (Lupinus albus L.). Materialy konferencji "Genetika 2000". Krakyw, Poland.

Kazimierski, T. and E.M. Kazimierska. 1994. The course of meiosis and microsporogenesis in dihaploid plants of white lupin (L. albus L.). Genet. Pol. 35(3):153-160.

Komarov, V.L. 1931. Origin of cultivated plants. State Printing Office, Moscow and Leningrad, USSR. 200 pp. Komarov, V.L. 1944. The doctrine about a species at plants. Leningrad, USSR. 285 pp.

Korovina, O.N. 1987. N.I. Vavilov on the primary centres of cultivated plant origin. Bot. Journal, St. Petersburg 6:721729.

Korsakov, N.I. 1971. Geographical seats of soybean formation. Bull. Appl. Bot. Genet. Plant Breed. 45:189-193.

Krassilov, V.A. 1989. Vavilov's species concept and evolution of variation. Evolutionary Theory, 9: 37-44.

Kurlovich, B.S. 1989. On the centers of species formation of the genus Lupinus L. Bull. VIR 193:20-24.

Kurlovich, B.S. and A.K. Stankevich. 1990. Intraspecific diversity of three annual lupine species (Lupinus L.). Bull. Appl. Bot. Genet. Plant Breed. 135:19-34.

Kurlovich, B.S., S.I. Rep'ev, L.G. Shchelko, V.I. Budanova, M.V. Petrova, T.V. Buravtseva, A.K. Stankevich, L.T. Kartuzova, T.G. Alexandrova, T.E. Teplyakova and L.K. Malysh. 1995. Theoretical basis of plant breeding. Vol. III. The gene bank and breeding of grain legumes (lupine, vetch, soya and bean). VIR, St. Petersburg, Russia. 438 p.

Kurlovich, B.S. 1996a. Georgian ecotype of white lupine (Lupinus albus L.). Plant Genetic Resources Newsletter, Rome, 108:66-68.

Kurlovich, B.S. 1996b. Genetic resources of grain legume crops in N.I. Vavilov All-Russian Research Institute of Plant Industry. Pp.77-81 in: Report of a Working Group on Grain Legumes (T. Gass, M. Ambrose, J. Le Guen, A. Hadjichristodoulou and S. Blixt, comps). ECP/GR-Grain Legumes Network, IPGRI, Rome, Italy.

Kurlovich, B.S. 1998. Species and intraspecific diversity of white blue and yellow lupins. Plant Genet. Resources Newsletter. 115:1-10.

Kurlovich, B.S. 2002. LUPINS: Geography, Classifications, Genetic Resources and Breeding.// St. Petersburg, Publishing house «Intan», 468p.

Kurlovich, B.S. 2015. Diversity of Lupinus albus L., Lupinus angustifolius L. and Lupinus luteus L. P.142 in: Developing lupin into a major and sustainable food and feed source (Jessica Capraro et al. eds.). Proceedings of the 15th International Lupin Conference, Milan, Italy, 21-26 Lune 2015.

Linnaeus, Carolus (1735). Systemanaturae, sive regna trianaturaesystematiceproposita per classes, ordines, genera, \& species. Leiden: Haak. pp. 1-12.

Mayden RL. 1997. A hierarchy of species concepts: The denouement in the saga of the species problem. In: Claridge MFH, Dawah HA, Wilson MR, editors. Species: The Units of Diversity. London: Chapman and Hall. p 381-423.

Maissurjan, N.A. and A.I. Atabekova. 1974. Lupine. Kolos, Leningrad, USSR. 463 p.

Makasheva, R. Kh. 1973. Pea. Kolos, Leningrad, USSR. 311 p. 
Makasheva, R. Kh. 1979. Pea. Flora of cultivated plants. V. IV, part 1. Kolos, Leningrad, USSR. 322 p.

Mota, M. 1984. Lupin germplasm resources in Portugal. p. 8 in Abstracts of the IIIrd International Lupin Conference, La Rochelle, France.

Neves Martins, J.M. 1994. Numerical taxonomy on the study of Lupinus albus accessions. Pp. 84-89 in Advances in Lupin Research: Proceedings of the 7th International Lupin Conference, Evora, Portugal, 1993 (J.M. Neves Martins and L.M. Вегдо da Costa, eds.). ISA Press, Lisbon, Portugal.

Pavlova, A.M. 1952. Varieties of mung bean for new regions of irrigation. Bull. Appl. Bot. Genet. Plant Breed. 29(3):6770.

Polhill, R.M. 1976. Genisteae (Adans.) Benth. and related tribes (Leguminosae). Bot. Systematics 1:143-368. Popova, G.M. 1937. Phaseolus aureus (Roxb.). Piper - Mung pea. Pp. 573-601 in Flora of cultivated plants. VIR, Leningrad, USSR.

Rep'ev, S.I. 1988. Principles governing selection of parental pairs in the transgressive breeding of common vetch. Bull. Appl. Bot. Genet. Plant Breed. 117:69-76.

Rep'ev, S.I. and V.N. Barulin. 1998. Human Being: Information, Systems of Interaction, Heredity. Theory and Practice. Intan, St. Petersburg, Russia. 116 pp. (in Russian).

Seferova, I.V. 1997. Varieties of chickpea - Cicer arietinum L. Bull. Appl. Bot. Genet. Plant Breed. 152:9-18.

Sinskaja, E.N. 1969. The historical geography of flora of cultivated plants. Leningrad, USSR. 480 p.

Stankevich A.K. and S.I. Rep'ev, 1999. Vetch. Flora of cultivated plants, 490 p.

Swęcicki, W. 1988. Lupin gene resources in the Old World. Pp.2-11 in Proceedings of the 5th International Lupin Conference (T. Twardowsky, ed.). PWRiL, Poznan, Poland.

Sweetingham, M.W. 1986. Research into lupin root diseases. West. Aust. J. Agr. 27:49-52.

Sweetingham, M.W. 1989. Fungi associated with root and hypocotyl diseases of seedling lupin. Research into lupin root diseases. West. Aust. J. Agr. 40:781-789.

Tavares de Sousa, M.M., I. M. Duarte and M.G. Pereira. 1992. Potential production of winter chickpea in southern Portugal. In: Proceedings of the International Food Legume Research Conference II, Cairo, Egypt, 12-16 April.

Teplyakova, T.E. 1997. Nomenclature analysis of the basis taxonomic systems in soya (Glycine max (L.) Merr.). Bull. Appl. Bot. Genet. Plant Breed. 152:111-118.

Tigerstedt, P.M.A. 1994. Adaptation, variation and selection in marginal areas. Pp. 13-19 in Breeding Fodder Crops for Marginal conditions (O.A. Rongli, E. Solberg and I. Schjelderup, eds.). Kluwer Academic Publishers, Dordrecht, the Netherlands.

Vavilov, N.I. 1920. The Law of Homologous Series in Hereditary Variation. Pp. 3-20 in Proceedings of the III AllRussian Plant Breeding Congress, Saratov, Russia.

Vavilov, N.I. 1926. Centres of origin of cultivated plants. Bull. Appl. Bot. Genet. Plant Breed. 16(2). 248 p.

Vavilov, N. I. 1931a. The Linnean species as a system / N. I. Vavilov (prof.) = [Линнеевскийвидкаксистема / Н. И. Вавилов] // Fifth International botanical congress, (Cambridge, 16-23 august, 1930) : report of proceedings. Cambridge: University press, 1931. - P. 213-216.

Vavilov, N.I. 1931b. Linnaeus species as a system. Bull. Appl. Bot. Genet. Plant Breed. 26(3):109-134.

Vavilov, N.I. 1935. Theoretical basis of plant breeding. VIR, St. Petersburg, USSR.

Vavilov, N.I. 1940. The doctrine about an origin of cultural plants after Darwin. Sov. Sci. 2:55-75.

Vavilov, N.I. 1962. Five Continents. State Publishing House of the Geographical Literature, Moscow, USSR. 225 p.

Vavilov, N.I. 1965a. Linnaeus species as a system. pp. 223-250 in: The selected works. 5 vols. State Printing Office, Moscow and Leningrad, USSR.

Vavilov, N.I. 1965b. Origin and geography of cultural plants. p. 179 in: The selected works. 5 vols. State Printing Office, 
Moscow and Leningrad, USSR.

Vavilov, N.I. 1987a. Five Continents. Science Publishing House, Leningrad, USSR. 213 pp.

Vavilov, N.I. 1987b. Origin and geography of cultivated plants. VIR, St. Petersburg, USSR.

Vavilov, N.I. 1991. Near the Pamirs (Darvaz, Roshan, Shugnan). Agricultural essay. Bull. Appl. Bot. Genet. Plant Breed. 140:1-12.

Vavilov, N.I. 1997. Five Continents (L.E. Rodin, S. Reznik and P. Stapleton, eds.). IPGRI, Rome, Italy. 198 p.Wilkins J. 2006. Reports of NCSE 26 (4), Species, Kinds, and Evolution. https://ncse.com/library-resource/species-kinds-evolution

Wojciechowski, M.F. 2003 Reconstructing the phylogeny of legumes (Leguminosae): an early 21st century perspective //In: B.B. Klitgaard and A. Bruneau (editors). //Advances in Legume Systematics, part 10, Higher Level Systematics, pp. 5-35. Royal Botanic Gardens, Kew.

Yakovlev G.P., Sytin A.K., \&Yu.R. Roskov. 1996 Legumes of Northern Eurasia // Royal Botanic gardens, Kew. 250p.

Zhukovsky, P.M. 1929. A contribution to the knowledge of genus Lupinus Tourn. Bull. Appl. Bot. Genet. Plant Breed. 21(1):16-294.

Zhukovsky, P.M. 1971. Cultivated plants and their relatives. Kolos, Leningrad, USSR. 751 p. 